\title{
Plasmapheresis in Immunologic Renal Disease
}

\author{
Charles D. Pusey Jeremy B. Levy \\ Renal Section, Department of Medicine, Imperial College London, London, UK
}

\section{Key Words}

Plasmapheresis - Therapeutic plasma exchange $\cdot$ Renal disease $\cdot$ Glomerulonephritis $\cdot$ Renal transplantation . Autoantibodies $\cdot$ Immune complexes

\begin{abstract}
Plasmapheresis has been used in the management of immunologic renal disease for the last 40 years. The rationale behind this approach is to remove pathogenic immune mediators, such as autoantibodies and immune complexes, from the circulation. There may also be benefit in depleting proinflammatory molecules, such as complement components and coagulation factors. Initial experience was gained in Goodpasture's disease, in which antiglomerular basement membrane antibodies were known to be pathogenic. More recently, a role for autoantibodies has become clear in smallvessel systemic vasculitis and some cases of hemolytic uremic syndrome/thrombotic thrombocytopenic purpura. Removal of immune complexes is thought to be important in cryoglobulinemia and systemic lupus erythematosus. Plasmapheresis is used in renal transplantation for the treatment of acute antibody-mediated rejection, and for desensitization of patients with preformed anti-HLA antibodies or those receiving an $\mathrm{ABO}$-incompatible transplant. Although many of the early studies were uncontrolled, there has been an increasing number of randomized controlled trials in recent years. The aim of this article is to summarize current indications for the use of plasmapheresis in immunologic renal disease.
\end{abstract}

Copyright @ 2012 S. Karger AG, Basel

\section{KARGER}

Fax +41613061234

E-Mail karger@karger.ch

www.karger.com
(C) 2012 S. Karger AG, Basel

$0253-5068 / 12 / 0333-0190 \$ 38.00 / 0$

Accessible online at:

www.karger.com/bpu

\section{Introduction}

Plasmapheresis was introduced into the management of immunologic renal disease in the mid-1970s when it was reported to be of benefit in addition to immunosuppressive drugs in the management of Goodpasture's disease [1]. Since then, plasmapheresis, or therapeutic plasma exchange (TPE), has been used in a variety of renal diseases in which there is evidence for the role of circulating factors such as autoantibodies or immune complexes in pathogenesis. Much of the early literature consists of case reports or uncontrolled series, but in the last few years there has been an increasing number of controlled studies comparing TPE with standard therapy [2]. The American Society for Apheresis produced helpful guidelines on the evidence-based use of TPE in $2007[3,4]$.

\section{Mechanism of Action}

TPE effectively removes large molecular weight substances from the plasma, including antibodies, immune complexes, complement components, and coagulation cascade factors. Early experience confirmed that antiGBM (glomerular basement membrane) antibodies were effectively removed in Goodpasture's disease, but that additional immunosuppressive therapy was required to prevent their resynthesis. Recent controlled trials in systemic vasculitis associated with antineutrophil cyto-

Charles D. Pusey

Renal Section, Department of Medicine, Imperial College London

Hammersmith Campus

Du Cane Road, London W12 0NN (UK)

Tel. +44 208383 3152, E-Mail c.pusey@ imperial.ac.uk 
plasm antibodies (ANCA) confirmed that this approach can be successful. However, our understanding of pathogenic mechanisms suggests that TPE may have benefits in addition to removal of autoantibodies, e.g. reduction in the concentration of complement components or coagulation factors when albumen is used as a replacement.

The removal of different circulating macromolecules depends upon several factors, including their size and distribution between intra- and extravascular compartments. For example, IgM is removed more effectively than IgG since it is largely intravascular (fig. 1). TPE is also effective at removing immune complexes, as found in cryoglobulinemia and systemic lupus erythematosus, and improves reticuloendothelial function. Exchange of a single plasma volume can remove around $70 \%$ of IgG, and sustained reduction in antibody levels is usually achieved by around five exchanges [5]. In a recent controlled study of TPE in ANCA-associated vasculitis, seven exchanges were shown to improve recovery of renal function in patients with a serum creatinine $>500 \mu \mathrm{mol} / \mathrm{l}$, as compared with pulse methylprednisolone [6].

\section{Techniques of Plasmapheresis}

Plasmapheresis can be carried out by centrifugal cell separation or by hollow fiber plasma filters (fig. 2a, b) [7]. The use of centrifugal systems has the advantage that there is no upper limit to the molecular weight of the substances cleared. This may be a consideration when attempting to remove IgM or immune complexes. Plasma filtration is more easily performed on renal units since the technique is similar to that of hemodialysis. Highly permeable hollow fibers are used which allow adequate clearance of IgG, but are less effective for higher-molecular-weight proteins such as IgM and immune complexes. There is an increased risk of platelet loss in centrifugal devices, and hemolysis can occur if transmembrane pressures are too high in plasma filtration.

Adequate vascular access is required for all methods of TPE. This is often achieved using central venous catheters, but existing arteriovenous fistulae can be used. Centrifugal TPE can also be performed using peripheral access through large-bore intravenous cannulae since the blood flow rates required are generally low. Anticoagulation is required and poses some risk of bleeding in those with recent surgery or biopsy, and those with hemorrhage related to their disease, e.g. lung hemorrhage in systemic vasculitis. In general, citrate is used for centrifugal plasma exchange, and heparin for membrane plasma filtra-

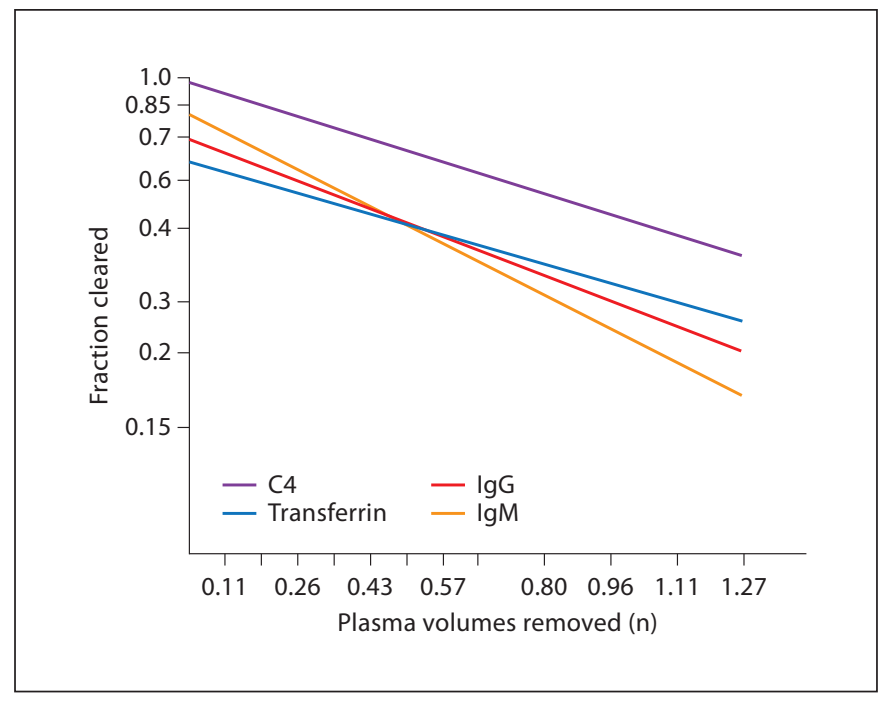

Fig. 1. Clearance of plasma proteins by plasma exchange. Clearance from the intravascular compartment varies with the plasma volume changed and between individual proteins [7].

tion. Citrate has an advantage in patients with a high risk of bleeding in view of the lack of systemic anticoagulant action. However, citrate is more likely to induce hypocalcemia, especially when using fresh-frozen plasma (FFP) as the replacement.

Large-volume TPE requires replacement with colloid in order to maintain oncotic pressure. Human serum albumin (HSA) is the mainstay of fluid replacement and induces fewer allergic complications than FFP. Almost all serious complications of plasma exchange have been reported in patients receiving FFP rather than $\operatorname{HSA}[8,9]$. There is a risk of depleting coagulation factors with HSA, and we recommend monitoring fibrinogen levels. If levels decrease to $<1.25 \mathrm{~g} / \mathrm{l}$, we recommend that FFP forms at least part of the replacement solution. FFP should also be used in patients with a high risk of bleeding, or in specific indications such as hemolytic uremic syndrome/ thrombotic thrombocytopenic purpura (HUS/TTP). In stable patients without a risk of bleeding, gelatin-based plasma expanders can safely be used as part of the replacement regimen.

A variety of alternative techniques to standard TPE have been described, but these will not be discussed in detail. They include the use of cascade filtration using a series of membranes of different pore size, and cryofiltration which cools the initial filtrate prior to reinfusion via a second filter. These techniques are not widely used at present. Selective and specific immunoadsorption has 


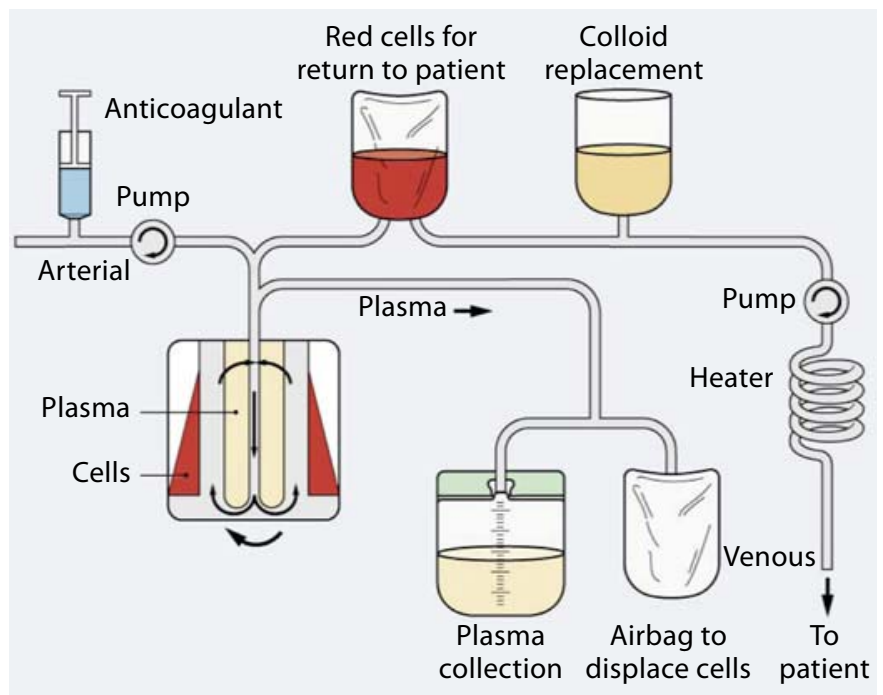

a

Fig. 2. Plasma exchange and immunoadsorption techniques. Techniques include centrifugal cell separation (a), hollow fiber membrane plasma filtration (b), and protein A immunoadsorption (c) [7].

also been reported. Protein A immunoadsorption has been used to selectively remove immunoglobulin from the plasma and reduce the need for replacement fluids (fig. 2c). The adsorption column can be regenerated after use and used on many occasions. Although there are reports that immunoadsorption is more effective than plasma exchange in diseases due to autoantibodies, there are no convincing controlled trials showing additional clinical benefit. Specific immunoadsorption has also been reported using specific ligands immobilized on columns,

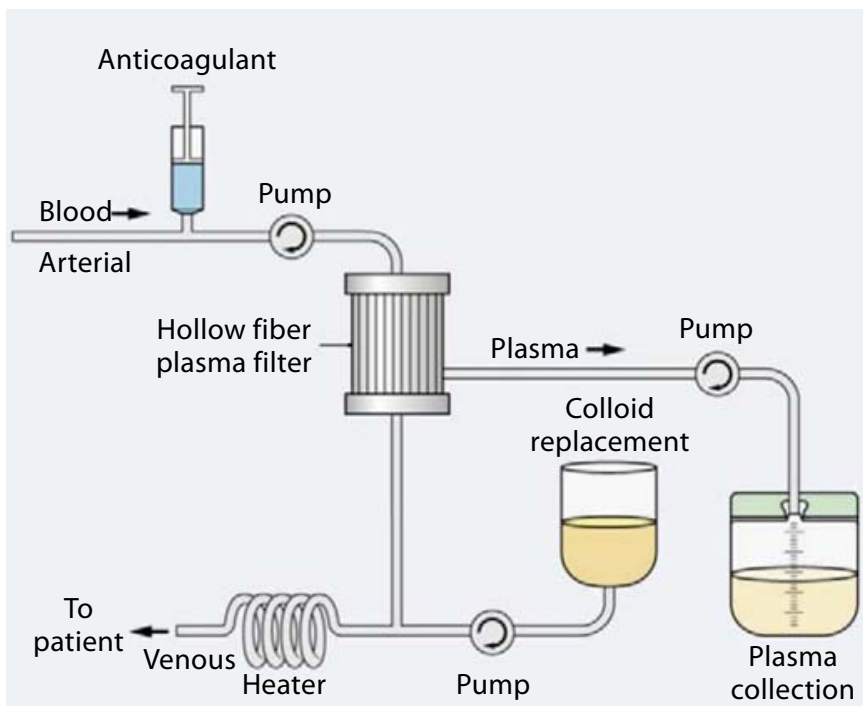

b

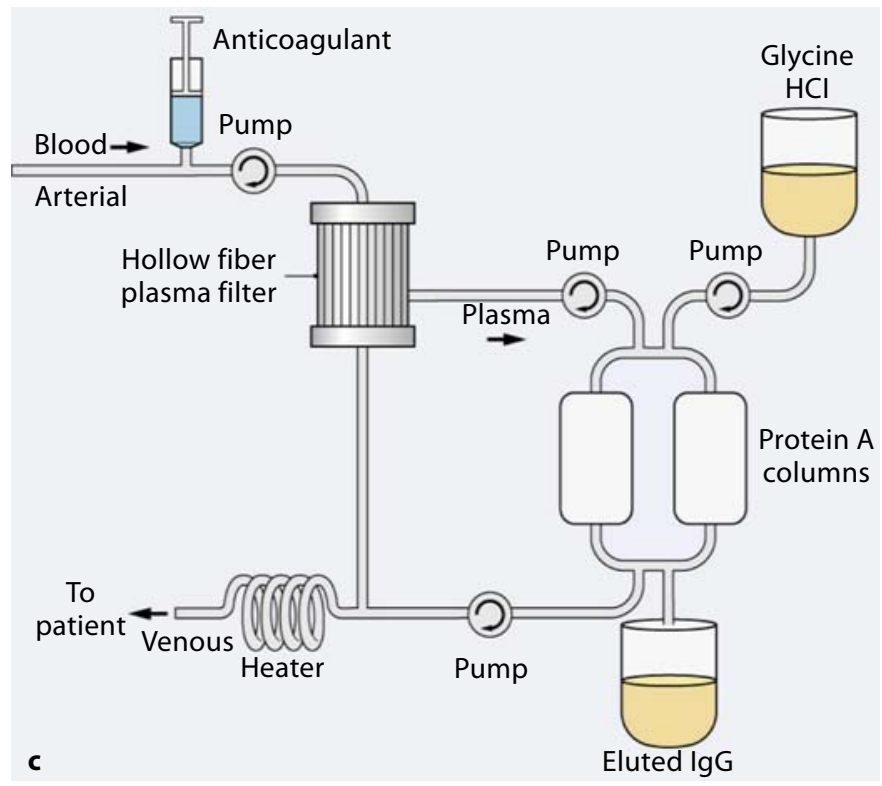

e.g. autoantigens and blood group antigens. Although of great theoretical interest, this approach is not yet widely used.

\section{Complications}

Complications of TPE are not common. They generally relate to complications of vascular access, allergic reactions to FFP, increased risk of bleeding, and symptoms 
Table 1. Conditions for which there is strong evidence for the benefit of plasma exchange [7]

\begin{tabular}{|c|c|c|c|c|c|}
\hline Indication & $\begin{array}{l}\text { Randomized } \\
\text { controlled trial } \\
\text { (number of } \\
\text { patients) }\end{array}$ & $\begin{array}{l}\text { Controlled } \\
\text { trial (num- } \\
\text { ber of } \\
\text { patients) }\end{array}$ & $\begin{array}{l}\text { Case series } \\
\text { (number of } \\
\text { patients) }\end{array}$ & Replacement fluid & Comments \\
\hline $\begin{array}{l}\text { ANCA-associated } \\
\text { systemic vasculitis }\end{array}$ & $8(300)$ & $1(26)$ & $21(294)$ & $\begin{array}{l}\text { albumin unless pulmonary } \\
\text { hemorrhage or need to prevent } \\
\text { coagulopathy }\end{array}$ & $\begin{array}{l}\text { only proven benefit in dialysis-dependent patients; } \\
\text { should consider daily exchanges in fulminant cases } \\
\text { or with pulmonary hemorrhage }\end{array}$ \\
\hline $\begin{array}{l}\text { Anti-GBM } \\
\text { antibody disease }\end{array}$ & $1(17)$ & 0 & $17(430)$ & $\begin{array}{l}\text { albumin unless pulmonary } \\
\text { hemorrhage or need to prevent } \\
\text { coagulopathy }\end{array}$ & $\begin{array}{l}\text { minimum course of } 14 \text { days to remove antibodies } \\
\text { effectively; especially beneficial in nonoliguric } \\
\text { patients before dialysis; patients with creatinine } \\
>5.5 \mathrm{mg} / \mathrm{dl}(500 \mu \mathrm{mol} / \mathrm{l}) \text { unlikely to benefit }\end{array}$ \\
\hline Cryoglobulinemia & 0 & 0 & $18(195)$ & albumin & $\begin{array}{l}\text { long-term maintenance treatment needed in } \\
\text { some patients; ensure blood warmer on return } \\
\text { lines or warm replacement fluids }\end{array}$ \\
\hline TTP & $3(237)$ & $2(133)$ & $17(915)$ & plasma or cryo-poor plasma & $\begin{array}{l}\text { daily, often with corticosteroids; } \\
\text { the only treatment that has improved mortality }\end{array}$ \\
\hline $\begin{array}{l}\text { ABO-incompatible } \\
\text { kidney transplantation }\end{array}$ & 0 & 0 & $22(>500)$ & $\begin{array}{l}\text { albumin } \pm \text { plasma (compatible } \\
\text { with donor and recipient or } \mathrm{AB} \text { ) }\end{array}$ & $\begin{array}{l}\text { used before transplantation to reduce titers of } \\
\text { antibodies and often continued for a few days } \\
\text { after surgery; allows successful transplantation }\end{array}$ \\
\hline $\begin{array}{l}\text { HLA desensitization } \\
\text { for transplantation } \\
\text { (in highly sensitized } \\
\text { patients) }\end{array}$ & 0 & $1(61)$ & $18(219)$ & albumin & $\begin{array}{l}\text { always in combination with immunosuppression } \\
\text { and continued until crossmatch negative; } \\
\text { usually needs } 5 \text { plasma exchanges to reduce } \mathrm{Ab} \\
\text { levels sufficiently }\end{array}$ \\
\hline $\begin{array}{l}\text { Antibody-mediated } \\
\text { kidney transplant } \\
\text { rejection }\end{array}$ & $3(61)$ & $5(240)$ & $24(396)$ & albumin & $\begin{array}{l}\text { daily or alternate day; significantly better evidence } \\
\text { has emerged in the last } 15 \text { years for benefit }\end{array}$ \\
\hline
\end{tabular}

related to hypocalcemia. A Swedish Registry report revealed no fatalities during more than 20,000 procedures, with an overall adverse incidence rate of $4.3 \%$, and only $0.9 \%$ for severe adverse events [9]. A Canadian Apheresis Registry report on over 144,000 procedures showed adverse events in $12 \%$ of procedures (mostly minor), and severe events in only $0.4 \%$ of procedures [10]. The World Apheresis Registry reported adverse events in $5.7 \%$ of over 12,000 procedures, severe adverse events in only $0.5 \%$, and no deaths [11]. Our own recent study of around 1,200 procedures in the UK reported adverse events in only $1.7 \%$, with no deaths [12].

\section{Indications for Plasmapheresis}

The evidence for the benefit of TPE in renal diseases is variable in quality, although the number of controlled trials is increasing. Evidence for the use of TPE in various diseases, including renal disease, was reported by the American Society for Apheresis in 2007, and reviews the available trial data at that time (tables 1,2$)[3,4]$. We will consider the indications for TPE in renal disease based on the published literature and our own experience at Hammersmith Hospital.

\section{Anti-GBM Disease}

TPE effectively removes anti-GBM antibodies and most patients are depleted of circulating antibodies after 10-14 exchanges, provided further antibody synthesis is prevented by immunosuppressive drugs. Prior to the introduction of this approach, mortality of anti-GBM disease was around $90 \%$ and very few patients recovered renal function. The introduction of plasma exchange in the mid-1970s led to a considerable improvement in outcome [1]. One-year survival in recent series is now between 70 and $90 \%$, and renal recovery is good in those with a creatinine of $<500 \mu \mathrm{mol} / \mathrm{l}$ at presentation, but still only around $10 \%$ in those who are dialysis-dependent [13].

One small controlled trial randomized patients to receive steroids and cyclophosphamide, or the same drugs 
Table 2. Conditions for which there is some evidence for the benefit of plasma exchange [7]

\begin{tabular}{|c|c|c|c|c|c|}
\hline Indication & $\begin{array}{l}\text { Randomized } \\
\text { controlled } \\
\text { trial (number } \\
\text { of patients) }\end{array}$ & $\begin{array}{l}\text { Controlled } \\
\text { trial (num- } \\
\text { ber of } \\
\text { patients) }\end{array}$ & $\begin{array}{l}\text { Case series } \\
\text { (number of } \\
\text { patients) }\end{array}$ & $\begin{array}{l}\text { Replace- } \\
\text { ment fluid }\end{array}$ & Comments \\
\hline $\begin{array}{l}\text { Catastrophic } \\
\text { antiphospholipid } \\
\text { antibody syndrome }\end{array}$ & 0 & 0 & $(280)$ & plasma & $\begin{array}{l}\text { should be done daily; combination of plasma exchange or } \\
\text { intravenous immunoglobulin, heparin, and corticosteroids (from } \\
\text { registry data) gives best outcomes }\end{array}$ \\
\hline $\begin{array}{l}\text { Primary or recurrent } \\
\text { FSGS }\end{array}$ & 0 & 0 & $40(98)$ & albumin & $\begin{array}{l}\text { sometimes in combination with cyclophosphamide; } \\
\text { may be more effective in recurrent disease after transplantation; } \\
\text { may need long-term maintenance treatment }\end{array}$ \\
\hline $\begin{array}{l}\text { Atypical HUS or } \\
\text { thrombotic } \\
\text { microangiopathy }\end{array}$ & $1(35)$ & $1(37)$ & $49(>1,000)$ & $\begin{array}{l}\text { plasma or } \\
\text { cryo-poor } \\
\text { plasma }\end{array}$ & $\begin{array}{l}\text { conflicting reports on benefit in atypical HUS but prognosis without } \\
\text { very poor; daily plasma exchange initially but duration variable }\end{array}$ \\
\hline Myeloma & $5(182)$ & 0 & $6(105)$ & albumin & $\begin{array}{l}\text { daily or alternate daily for } 7-10 \text { exchanges; despite negative } \\
\text { randomized trial in 2005, plasma exchange should be considered } \\
\text { if high light-chain load, severe renal failure, and oliguria despite } \\
\text { aggressive hydration and conservative management }\end{array}$ \\
\hline $\begin{array}{l}\text { Rapidly progressive } \\
\text { glomerulonephritis (may } \\
\text { include patients with } \\
\text { ANCA-associated disease } \\
\text { in older literature) }\end{array}$ & $7(196)$ & 0 & $20(273)$ & albumin & $\begin{array}{l}\text { no good evidence for benefit in immune complex disease of any } \\
\text { cause }\end{array}$ \\
\hline Scleroderma & 0 & $3(75)$ & $6(60)$ & albumin & $\begin{array}{l}\text { no good evidence for benefit, but some patients have reported } \\
\text { improvement with therapeutic trial of plasma exchange }\end{array}$ \\
\hline $\begin{array}{l}\text { Systemic lupus erythe- } \\
\text { matosus (not nephritis) }\end{array}$ & $1(20)$ & $1(4)$ & $13(124)$ & albumin & for cerebritis, lupus-associated TTP, or pulmonary hemorrhage \\
\hline
\end{tabular}

together with plasma exchange [14]. Only 2 of 8 patients receiving plasma exchange developed end-stage renal disease, compared with 6 of 9 receiving drugs alone. However, the trial was underpowered to show a significant effect.

In the largest long-term study of patients treated with plasma exchange and immunosuppressive drugs, almost all patients with a creatinine of $<500 \mu \mathrm{mol} / \mathrm{l}$ recovered kidney function, as did over $80 \%$ of those with creatinine $>500 \mu \mathrm{mol} / \mathrm{l}$, but not on dialysis. However, very few dialysis-dependent patients (8\%) regained independent renal function. Long-term follow-up revealed a good outcome in those patients regaining independent renal function [15].

We therefore recommend that all patients not already on dialysis receive intensive plasma exchange: initially for 14 days or until anti-GBM antibodies are undetectable, using HSA but adding FFP in those with recent biopsy or concomitant pulmonary hemorrhage. The use of TPE in patients already on dialysis is more controversial, but we would generally use it in those with recent onset disease, or where the renal biopsy reveals additional factors such as acute tubular necrosis that may account for the severity of renal failure. Lung hemorrhage provides a separate indication for TPE, and resolved in around 90\% of patients in our study [15].

\section{ANCA-Associated Vasculitis}

The majority of patients with rapidly progressive glomerulonephritis have small-vessel vasculitis associated with the presence of ANCA. There is increasing evidence that ANCA are pathogenic, providing a rationale for their removal. Since ANCA were not identified until the mid1980s, early studies of plasma exchange in patients with vasculitis were performed because of the similarity in histological changes to those in anti-GBM disease and the possibility that immune complexes were involved in pathogenesis. Although some early trials showed no benefit of plasma exchange, a trial performed in our hospital showed a benefit of TPE in addition to prednisolone and cyclophosphamide in those patients who were already on dialysis [16]. 
More recently, a randomized controlled trial performed by the European Vasculitis Study Group showed that plasma exchange was of significant benefit compared with the use of intravenous methylprednisolone in patients with serum creatinine $>500 \mu \mathrm{mol} / \mathrm{l}$ [6]. Around $70 \%$ of patients recovered renal function with TPE, compared with around $50 \%$ of those receiving methylprednisolone. Another recent study demonstrated that TPE may be of benefit in recovery of renal function in patients with a creatinine $>250 \mu \mathrm{mol} / \mathrm{l}$ [17]. A meta-analysis of plasma exchange in ANCA-associated vasculitis confirmed a significant benefit of adjunctive plasma exchange compared with standard therapy in the development of end-stage renal disease, and also in the composite endpoint of end-stage renal disease or death [18].

A large international trial (PEXIVAS) is now under way to examine the effect of plasma exchange and steroid dosage in patients with glomerulonephritis due to ANCA-associated vasculitis. Pending the results of this trial, we recommend the use of TPE in patients with a creatinine $>500 \mu \mathrm{mol} / \mathrm{l}$, and it should also be considered in those with a lower creatinine which is rising rapidly. We also suggest TPE for patients with lung hemorrhage, or other life-threatening features of systemic vasculitis [19].

\section{Other Crescentic Glomerulonephritis}

Crescent formation may be a feature of other forms of primary glomerulonephritis, including IgA nephropathy, membranoproliferative glomerulonephritis, and occasionally membranous nephropathy. It can also occur in postinfectious glomerulonephritis and glomerulonephritis associated with infective endocarditis. Although some of these cases were included in early studies of plasma exchange in rapidly progressive glomerulonephritis, there is no convincing evidence for the benefit of plasma exchange [3]. However, we and others have observed improved renal function following TPE in some of these patients. We cannot make firm recommendations, but regard the use of plasma exchange as reasonable in those patients with active crescentic nephritis and deteriorating renal function.

\section{Focal Segmental Glomerulosclerosis}

The role of circulating factors in focal segmental glomerulosclerosis (FSGS) is supported by the rapid recurrence of proteinuria in patients following renal trans- plantation. The circulating factor responsible has proved difficult to define, but a recent report suggests a role for a soluble urokinase receptor. Treatment of primary FSGS is complicated by the fact that some of these patients will have a genetic defect in proteins contributing to the glomerular filtration barrier. Perhaps as a result of this, the use of TPE in primary FSGS has produced variable results and cannot be generally recommended. However, in patients with recurrent FSGS following renal transplantation, TPE is frequently reported to be of benefit [20-22]. We therefore recommend TPE in patients with rapid onset of proteinuria following renal transplantation.

\section{Systemic Lupus Erythematosus}

TPE has been widely used in the treatment of lupus nephritis in order to remove circulating autoantibodies and immune complexes. There are few controlled trials, but one randomized prospective trial showed no benefit of the addition of plasmapheresis to a treatment regimen of prednisolone and cyclophosphamide in patients with lupus nephritis followed-up for almost 3 years [23]. However, patients with crescentic nephritis and those on dialysis were excluded, and it is perhaps unlikely that a short-term intervention would have long-term effects in this disease. A study in which high-dose cyclophosphamide was synchronized with plasmapheresis also failed to show positive results [24]. However, there are many anecdotal reports of the benefit of TPE in specific circumstances, such as patients with crescentic nephritis, pulmonary hemorrhage, cerebral lupus, or catastrophic antiphospholipid syndrome. Our own experience suggests that TPE should be considered as an acute intervention in those patients with life-threatening lupus. There are also reports of the successful use of immunoadsorption using protein A or anti-IgG columns in patients with severe disease unresponsive to conventional therapy.

\section{Cryoglobulinemia}

Although plasmapheresis has been used for treatment of cryoglobulinemia for many years, there are no controlled trials. In type 1 cryoglobulinemia, often associated with underlying lymphoma or myeloma, the monoclonal immunoglobulin responsible is readily removed by TPE. This can reverse the hyperviscosity and cryoprecipitation in this disorder, and there are many anecdotal 
reports of its effectiveness. In type 2 cryoglobulinemia, a monoclonal immunoglobulin, often IgM, has rheumatoid factor activity and complexes with IgG to produce circulating immune complexes. This disorder is frequently secondary to hepatitis $\mathrm{C}$ or related to an underlying lymphoma. Immune complex deposition often leads to mesangiocapillary glomerulonephritis and to widespread vasculitis. Plasmapheresis is effective in clearing these immune complexes and has widely been reported to improve the clinical features of cryoglobulinemia [25, 26]. Antiviral therapy is also used in those with hepatitis $\mathrm{C}$, and many studies have combined TPE with immunosuppressive drugs to prevent further paraprotein production. Some patients have been successfully treated with long-term intermittent TPE to control their symptoms. Cryofiltration and cascade filtration have both been used to selectively remove cryoglobulins, but these techniques are not widely available. We suggest that TPE be used as an initial therapy in patients with acute manifestations of cryoglobulinemia.

\section{Multiple Myeloma}

Multiple myeloma can lead to renal impairment through a wide variety of mechanisms, the commonest of which is light-chain cast nephropathy. Although TPE effectively removes the paraprotein responsible, early trials produced conflicting results. A more recent, larger study failed to show a significant benefit of plasmapheresis in addition to standard chemotherapy [27]. However, few of these patients had confirmed cast nephropathy on renal biopsy. A retrospective study from the Mayo Clinic suggested a benefit of TPE in patients with cast nephropathy who had high light-chain levels and severe renal impairment [28]. There are recent reports of the benefit of removal of free light-chains by hemodialysis using a high cut-off dialyzer [29]. There is an ongoing study (EULITE) to investigate this promising approach. Pending results of further trials, we suggest that TPE be used in patients with acute renal failure, high light-chain levels and cast nephropathy on renal biopsy.

\section{Hemolytic Uremic Syndrome/Thrombotic Thrombocytopenic Purpura}

Both HUS and TTP lead to thrombotic microangiopathy, which in HUS commonly affects the kidney. HUS is often divided into those cases preceded by diarrhea (D+), or those not preceded by diarrhea and which may have a familial basis (D-). In D+ HUS in children, treatment is supportive and most patients will recover fully. There are no randomized trials of TPE, although there are several studies of other approaches such as infusion of FFP, none of which have shown significant benefit [30]. There are, however, recent reports of the benefit of TPE in adults with severe acute onset D+ HUS [31].

Different pathogenic mechanisms have recently been identified in D- HUS and TTP. D- HUS is often associated with defective regulation of complement and TTP with deficiency of the von Willebrand factor cleaving protease (ADAMTS13). In these disorders, there may be an underlying genetic defect in complement, regulatory proteins or ADAMTS13, or the development of autoantibodies to them. Use of TPE, with FFP as replacement fluid, may be of benefit by removing pathogenic autoantibodies or replacing normal serum components. There are several anecdotal reports of the benefit of TPE with FFP for D- HUS. In TTP, there are two studies showing the benefit of plasmapheresis with FFP, compared with FFP infusions [32]. A meta-analysis of controlled trials in TTP suggests that plasmapheresis with FFP is the most effective approach [33]. Pending further studies, we would recommend using plasma exchange with FFP as initial treatment in adults with acute HUS or TTP.

\section{Renal Transplantation}

Plasmapheresis has been used since the 1980s for treatment of antibody-mediated rejection, and more recently as part of desensitization protocols for $\mathrm{ABO}$-incompatible renal transplants [34] and for patients with preformed anti-HLA antibodies [35]. Although there is mounting evidence for the benefit of TPE in these situations, the indications are not yet clear-cut. In acute antibody-mediated rejection, several trials have suggested benefit of plasmapheresis, usually combined with intravenous immunoglobulin $[36,37]$. Reversal of acute rejection has been reported in $55-100 \%$ of episodes. There appears to be no benefit in patients with chronic rejection. Plasmapheresis has also been reported to be effective in allowing transplantation of highly sensitized patients with preformed anti-HLA antibodies [38, 39]. Patients usually receive intensive plasmapheresis, sometimes combined with immunosuppressive drugs, prior to transplantation. Protein A immunoadsorption has also been reported to be effective [40]. In some series, plasma exchange has been continued after transplantation in order to keep an- 
tibody levels low. The use of this approach has led to 1 -year graft survival rates in excess of $70 \%$. A similar approach has been adopted for ABO-incompatible transplantation, in which plasmapheresis is used to deplete anti-A or anti-B antibodies prior to transplantation [41, 42]. Rituximab is commonly used as part of the desensitization protocol. One-year graft survival of around $80 \%$ has been reported, although early humoral rejection remains a problem and may need further treatment with TPE. On current evidence, we recommend TPE together with intravenous immunoglobulin for acute antibodymediated rejection. TPE is also of value as part of desensitization protocols for high-risk patients in specialist units.

\section{References}

1 Lockwood CM, Boulton-Jones JM, Lowenthal RM, Simpson IJ, Peters DK: Recovery from Goodpasture's syndrome after immunosuppressive treatment and plasmapheresis. Br Med J 1975;2:252-254.

-2 Baweja S, Wiggins K, Lee D, Blair S, Fraenkel M, McMahon LP: Benefits and limitations of plasmapheresis in renal diseases: an evidence-based approach. J Artif Organs 2011; 14:9-22.

3 Szczepiorkowski ZM, Bandarenko N, Kim $\mathrm{HC}$, et al: Guidelines on the use of therapeutic apheresis in clinical practice: evidencebased approach from the Apheresis Applications Committee of the American Society for Apheresis. J Clin Apher 2007;22:106-175.

4 Shaz BH, Linenberger ML, Bandarenko N, et al: Category IV indications for therapeutic apheresis: ASFA fourth special issue. J Clin Apher 2007;22:176-180.

5 Derksen RH, Schuurman HJ, Meyling FH, Struyvenberg A, Kater L: The efficacy of plasma exchange in the removal of plasma components. J Lab Clin Med 1984;104:346354

-6 Jayne DR, Gaskin G, Rasmussen N, et al: Randomized trial of plasma exchange or high-dosage methylprednisolone as adjunctive therapy for severe renal vasculitis. J Am Soc Nephrol 2007; 18:2180-2188.

7 Levy J, Pusey CD: Plasma exchange; in Johnson RJ, Floege J, Feehally J (eds): Comprehensive Clinical Nephrology, ed 3. London, Harcourt Publishers, 2007, pp 1013-1020.

-8 Reutter JC, Sanders KF, Brecher ME, Jones HG, Bandarenko N: Incidence of allergic reactions with fresh frozen plasma or cryo-supernatant plasma in the treatment of thrombotic thrombocytopenic purpura. J Clin Apher 2001;16:134-138.

-9 Norda R, Stegmayr BG: Therapeutic apheresis in Sweden: update of epidemiology and adverse events. Transfus Apher Sci 2003;29: 159-166.

10 Rock G, Clark B, Sutton D: The Canadian Apheresis Registry. Transfus Apher Sci 2003; 29:167-177.

-11 Stegmayr B, Ptak J, Wikstrom B, et al: World Apheresis Registry 2003-2007 data. Transfus Apher Sci 2008;39:247-254.
12 Pusey C, Dash C, Garrett M, et al: Experience of using human albumin solution 4.5\% in 1195 therapeutic plasma exchange procedures. Transfus Med 2010;20:244-249.

13 Pusey CD: Anti-glomerular basement membrane disease. Kidney Int 2003;64:15351550 .

14 Johnson JP, Whitman W, Briggs WA, Wilson CB: Plasmapheresis and immunosuppressive agents in antibasement membrane antibodyinduced Goodpasture's syndrome. Am J Med 1978;64:354-359.

15 Levy JB, Turner AN, Rees AJ, Pusey CD: Long-term outcome of anti-glomerular basement membrane antibody disease treated with plasma exchange and immunosuppression. Ann Intern Med 2001;134:10331042.

16 Pusey CD, Rees AJ, Evans DJ, Peters DK, Lockwood CM: Plasma exchange in focal necrotizing glomerulonephritis without anti-GBM antibodies. Kidney Int 1991;40:757763.

17 Szpirt WM, Heaf JG, Petersen J: Plasma exchange for induction and cyclosporine A for maintenance of remission in Wegener's granulomatosis - a clinical randomized controlled trial. Nephrol Dial Transplant 2011; 26:206-213.

18 Walsh M, Catapano F, Szpirt W, et al: Plasma exchange for renal vasculitis and idiopathic rapidly progressive glomerulonephritis: a meta-analysis. Am J Kidney Dis 2011;57: 566-574.

19 Klemmer PJ, Chalermskulrat W, Reif MS, Hogan SL, Henke DC, Falk RJ: Plasmapheresis therapy for diffuse alveolar hemorrhage in patients with small-vessel vasculitis. Am J Kidney Dis 2003;42:1149-1153.

20 Deegens JK, Andresdottir MB, Croockewit S, Wetzels JF: Plasma exchange improves graft survival in patients with recurrent focal glomerulosclerosis after renal transplant. Transpl Int 2004;17:151-157.

21 Gonzalez E, Ettenger R, Rianthavorn P, Tsai E, Malekzadeh M: Preemptive plasmapheresis and recurrence of focal segmental glomerulosclerosis in pediatric renal transplantation. Pediatr Transplant 2011;15:495-501.
22 Feld SM, Figueroa P, Savin V, et al: Plasmapheresis in the treatment of steroid-resistant focal segmental glomerulosclerosis in native kidneys. Am J Kidney Dis 1998;32: 230-237.

23 Lewis EJ, Hunsicker LG, Lan SP, Rohde RD, Lachin JM: A controlled trial of plasmapheresis therapy in severe lupus nephritis. The Lupus Nephritis Collaborative Study Group. N Engl J Med 1992;326:1373-1379.

24 Danieli MG, Palmieri C, Salvi A, Refe MC, Strusi AS, Danieli G: Synchronised therapy and high-dose cyclophosphamide in proliferative lupus nephritis. J Clin Apher 2002;17: 72-77.

25 Frankel AH, Singer DR, Winearls CG, Evans DJ, Rees AJ, Pusey CD: Type II essential mixed cryoglobulinaemia: presentation, treatment and outcome in 13 patients. Q J Med 1992;82:101-124.

26 Berkman EM, Orlin JB: Use of plasmapheresis and partial plasma exchange in the management of patients with cryoglobulinemia. Transfusion 1980;20:171-178.

27 Clark WF, Stewart AK, Rock GA, et al: Plasma exchange when myeloma presents as acute renal failure: a randomized, controlled trial. Ann Intern Med 2005; 143:777784 .

28 Leung N, Gertz MA, Zeldenrust SR, et al: Improvement of cast nephropathy with plasma exchange depends on the diagnosis and on reduction of serum free light chains. Kidney Int 2008;73:1282-1288.

29 Hutchison CA, Bradwell AR, Cook M, et al: Treatment of acute renal failure secondary to multiple myeloma with chemotherapy and extended high cut-off hemodialysis. Clin J Am Soc Nephrol 2009;4:745-754

30 Rizzoni G, Claris-Appiani A, Edefonti A, et al: Plasma infusion for hemolytic-uremic syndrome in children: results of a multicenter controlled trial. J Pediatr 1988;112: 284-290.

31 Colic E, Dieperink H, Titlestad K, Tepel M: Management of an acute outbreak of diarrhoea-associated haemolytic uraemic syndrome with early plasma exchange in adults from southern Denmark: an observational study. Lancet 2011;378:1089-1093. 
\$2 Rock GA, Shumak KH, Buskard NA, et al: Comparison of plasma exchange with plasma infusion in the treatment of thrombotic thrombocytopenic purpura. Canadian Apheresis Study Group. N Engl J Med 1991; 325:393-397.

33 Michael M, Elliott EJ, Ridley GF, Hodson EM, Craig JC: Interventions for haemolytic uraemic syndrome and thrombotic thrombocytopenic purpura. Cochrane Database Syst Rev 2009:CD003595.

-34 Tobian AA, Shirey RS, Montgomery RA, et al: ABO antibody titer and risk of antibodymediated rejection in $\mathrm{ABO}$-incompatible renal transplantation. Am J Transplant 2010; 10:1247-1253.

35 Snanoudj R, Candon S, Legendre C: Targeting $B$ cells in sensitized kidney transplant patients: state of the art and future perspectives. Curr Opin Organ Transplant 2010, Epub ahead of print.
36 White NB, Greenstein SM, Cantafio AW, et al: Successful rescue therapy with plasmapheresis and intravenous immunoglobulin for acute humoral renal transplant rejection. Transplantation 2004;78:772-774.

37 Rocha PN, Butterly DW, Greenberg A, et al Beneficial effect of plasmapheresis and intravenous immunoglobulin on renal allograft survival of patients with acute humoral rejection. Transplantation 2003;75:1490-1495

-38 Stegall MD, Gloor J, Winters JL, Moore SB, Degoey S: A comparison of plasmapheresis versus high-dose IVIG desensitization in renal allograft recipients with high levels of donor specific alloantibody. Am J Transplant 2006;6:346-351.
9 Higgins RM, Bevan DJ, Carey BS, et al: Prevention of hyperacute rejection by removal of antibodies to HLA immediately before renal transplantation. Lancet 1996;348:12081211.

40 Salama AD, Delikouras A, Pusey CD, et al: Transplant accommodation in highly sensitized patients: a potential role for Bcl-xL and alloantibody. Am J Transplant 2001;1:260269.

41 Winters JL, Gloor JM, Pineda AA, Stegall $\mathrm{MD}$, Moore SB: Plasma exchange conditioning for ABO-incompatible renal transplantation. J Clin Apher 2004;19:79-85.

42 Sonnenday CJ, Warren DS, Cooper M, et al: Plasmapheresis, CMV hyperimmune globulin, and anti-CD20 allow ABO-incompatible renal transplantation without splenectomy. Am J Transplant 2004;4:1315-1322. 